\title{
Mepivacaine-induced intracellular calcium increase appears to be mediated primarily by calcium influx in rat aorta without endothelium
}

\author{
Seong-Ho Ok ${ }^{1}$, Seong-Chun Kwon ${ }^{2}$, Sebin Kang ${ }^{3}$, Mun-Jeoung Choi ${ }^{4}$, and Ju-Tae Sohn ${ }^{1}$ \\ ${ }^{1}$ Department of Anesthesiology and Pain Medicine, Institute of Health Sciences, Gyeongsang National University Hospital, \\ Gyeongsang National University School of Medicine, Jinju, ${ }^{2}$ Department of Physiology, Catholic Kwandong University College of \\ Medicine, Gangneung, ${ }^{3}$ Department of Anesthesiology and Pain Medicine, Gyeongsang National University Hospital, ${ }^{4}$ Department of \\ Oral and Maxillofacial Surgery, Gyeongsang National University Hospital, Jinju, Korea
}

Background: Mepivacaine induces contraction or decreased blood flow both in vivo and in vitro. Vasoconstriction is associated with an increase in the intracellular calcium concentration $\left(\left[\mathrm{Ca}^{2+}\right]_{\mathrm{i}}\right)$. However, the mechanism responsible for the mepivacaine-evoked $\left[\mathrm{Ca}^{2+}\right]_{\mathrm{i}}$ increase remains to be determined. Therefore, the objective of this in vitro study was to examine the mechanism responsible for the mepivacaine-evoked $\left[\mathrm{Ca}^{2+}\right]_{\mathrm{i}}$ increment in isolated rat aorta.

Methods: Isometric tension was measured in isolated rat aorta without endothelium. In addition, fura-2 loaded aortic muscle strips were illuminated alternately $(48 \mathrm{~Hz}$ ) at two excitation wavelengths ( 340 and $380 \mathrm{~nm}$ ). The ratio of F340 to F380 (F340/F380) was regarded as an amount of $\left[\mathrm{Ca}^{2+}\right]_{\mathrm{i}}$. We investigated the effects of nifedipine, 2-aminoethoxydiphenylborate (2-APB), gadolinium chloride hexahydrate $\left(\mathrm{Gd}^{3+}\right)$, low calcium level and Krebs solution without calcium on the mepivacaine-evoked contraction in isolated rat aorta and on the mepivacaine-evoked $\left[\mathrm{Ca}^{2+}\right]_{\mathrm{i}}$ increment in fura-2 loaded aortic strips. We assessed the effect of verapamil on the mepivacaine-evoked $\left[\mathrm{Ca}^{2+}\right]_{\mathrm{i}}$ increment.

Results: Mepivacaine produced vasoconstriction and increased $\left[\mathrm{Ca}^{2+}\right]_{i}$. Nifedipine, 2-APB and low calcium attenuated vasoconstriction and the $\left[\mathrm{Ca}^{2+}\right]_{\mathrm{i}}$ increase evoked by mepivacaine. Verapamil attenuated the mepivacaine-induced $\left[\mathrm{Ca}^{2+}\right]_{\mathrm{i}}$ increment. Calcium-free solution almost abolished mepivacaine-induced contraction and strongly attenuated the mepivacaineinduced $\left[\mathrm{Ca}^{2+}\right]_{\mathrm{i}}$ increase. $\mathrm{Gd}^{3+}$ had no effect on either vasoconstriction or the $\left[\mathrm{Ca}^{2+}\right]_{\mathrm{i}}$ increment evoked by mepivacaine.

Conclusions: The mepivacaine-evoked $\left[\mathrm{Ca}^{2+}\right]_{\mathrm{i}}$ increment, which contributes to mepivacaine-evoked contraction, appears to be mediated mainly by calcium influx and partially by calcium released from the sarcoplasmic reticulum. (Korean J Anesthesiol 2014; 67: 404-411)

Key Words: Aorta, Calcium influx, Fura-2, Intracellular calcium concentration, Isometric tension, Mepivacaine.

Received: April 28, 2014. Revised: 1st, June 2, 2014; 2nd, June 21, 2014. Accepted: July 7, 2014.

Corresponding author: Ju-Tae Sohn, M.D., Department of Anesthesiology and Pain Medicine, Institute of Health Sciences, Gyeongsang National University Hospital, Gyeongsang National University School of Medicine, 79, Gangnam-ro, Jinju 660-702, Korea. Tel: 82-55-750-8586, Fax: 8255-750-8142, E-mail: jtsohn@nongae.gsnu.ac.kr

Seong-Ho Ok and Seong-Chun Kwon contributed equally to this study as co-first authors.

(c) This is an open-access article distributed under the terms of the Creative Commons Attribution Non-Commercial License (http:// creativecommons.org/licenses/by-nc/3.0/), which permits unrestricted non-commercial use, distribution, and reproduction in any medium, provided the original work is properly cited. 


\section{Introduction}

Mepivacaine, an intermediate-acting aminoamide local anesthetic that has a rapid onset time and a relatively low risk of toxicity, has been used for regional anesthesia, particularly in patients who have compromised cardiac function [1]. Mepivacaine causes the intrinsic vasoconstriction of blood vessels or attenuated blood flow both in vivo and in vitro [2-9]. The intrinsic vasoconstriction induced by local anesthetics seems to be partially correlated with the duration of analgesia the anesthetics produce $[10,11]$. Decreased perineural blood supply, which is the result of intrinsic contraction evoked by local anesthetic, may relate to decreased local anesthetic clearance $[10,11]$. Vasoconstriction is regulated by both calcium-dependent and calcium-sensitization mechanisms [12]. An increased intracellular calcium concentration $\left(\left[\mathrm{Ca}^{2+}\right]_{\mathrm{i}}\right)$ due to either calcium influx from extracellular fluid or calcium released from the sarcoplasmic reticulum contributes to the calcium-dependent mechanism responsible for vascular smooth muscle contraction [12]. Mepivacaine-induced contraction seems to be inhibited by endothelial nitric oxide, which is stimulated by endothelial $\left[\mathrm{Ca}^{2+}\right]_{\mathrm{i}}$ increment $[7,13]$. Mepivacaineevoked vasoconstriction involves increased calcium sensitivity, which is evoked by calcium influx from extracellular space [9]. However, the mechanism responsible for the $\left[\mathrm{Ca}^{2+}\right]_{\mathrm{i}}$ increase associated with mepivacaine-evoked vasoconstriction remains to be determined. Therefore, the objective of this in vitro study was to examine the mechanism (i.e., either calcium influx or calcium release from sarcoplasmic reticulum) that is responsible for the $\left[\mathrm{Ca}^{2+}\right]_{\mathrm{i}}$ increase, which contributes to the mepivacaine-evoked vasoconstriction of isolated rat aortas without endothelium.

\section{Materials and Methods}

Gyeongsang National University approved all experimental procedures and protocols. All experimental procedures were done in accordance with the Guide for the Care and Use of Laboratory Animals provided by the National Academy of Sciences.

\section{Preparation of aortic rings for tension measurement}

We prepared aortic rings for isometric tension measurement as previously described [14]. Anesthesia of male Sprague Dawley rats weighing 250-300 g was induced by intramuscular injection of Zoletil 50 (tiletamine $\mathrm{HCl} 125 \mathrm{mg}$ and zolazepam base $125 \mathrm{mg} / 5 \mathrm{ml} ; 15 \mathrm{mg} / \mathrm{kg}$; Virbac Laboratories, Carros, France). We dissected descending thoracic aorta, and removed surrounding connective tissues and fat under microscope in a Krebs solution bath. Krebs solution was composed of $118 \mathrm{mM}$ $\mathrm{NaCl}, 4.7 \mathrm{mM} \mathrm{KCl}, 1.2 \mathrm{mM} \mathrm{MgSO}$, $1.2 \mathrm{mM} \mathrm{KH}_{2} \mathrm{PO}_{4}, 2.4 \mathrm{mM}$ $\mathrm{CaCl}_{2}, 25 \mathrm{mM} \mathrm{NaHCO}_{3}$, and $11 \mathrm{mM}$ glucose. The aorta was cut into 2.5-mm-length rings that were suspended on Grass isometric transducers (FT-03, Grass Technologies, Warwick RI, USA) under $3.0 \mathrm{~g}$ resting tension in a $10 \mathrm{ml} \mathrm{Krebs}$ bath at $37^{\circ} \mathrm{C}$, and aerated continuously with $95 \% \mathrm{O}_{2}$ and $5 \% \mathrm{CO}_{2}$ to persist $\mathrm{pH}$ within the range of 7.35-7.45. We used $120 \mathrm{~min}$ for equilibrium of rings and changed the bathing solution every $30 \mathrm{~min}$. We removed endothelium from aortic rings using a 25 -gauge needle. When phenylephrine $\left(10^{-8} \mathrm{M}\right)$ produced a sustained contraction, we added acetylcholine $\left(10^{-5} \mathrm{M}\right)$ into organ bath, and less than $10 \%$ acetylcholine-induced relaxation was regarded as endothelial denudation. The magnitude of contraction evoked by isotonic $60 \mathrm{mM}$ potassium chloride $(\mathrm{KCl})$ was measured for all aortic rings and regarded as the reference value (100\%) for comparing contractile responses induced by mepivacaine. After washing out the $\mathrm{KCl}$ from the organ bath with fresh Krebs solution and reaching to the recovery of the baseline resting tension, mepivacaine-evoked dose-response curves were obtained (detailed below). The Krebs solution also included the nitric oxide synthase inhibitor $\mathrm{N}^{\mathrm{w}}$-nitro-L-arginine methyl ester (L-NAME, $10^{-4} \mathrm{M}$ ) to prevent the nitric oxide release due to remaining residual endothelium $[15,16]$.

\section{Experimental protocols}

We assessed cumulative mepivacaine dose $\left(10^{-5}\right.$ to $\left.10^{-2} \mathrm{M}\right)$ response curves in aortas without endothelium pretreated with or without the following inhibitors: voltage-operated calcium channel (VOCC) inhibitor nifedipine $\left(10^{-8}, 10^{-7}\right.$ and $\left.10^{-6} \mathrm{M}\right)$, inositol 1,4,5-trisphosphate $\left(\mathrm{IP}_{3}\right)$ receptor blocker 2-aminoethoxydiphenylborate (2-APB: $5 \times 10^{-6}, 10^{-5}$ and $\left.5 \times 10^{-5} \mathrm{M}\right)$ and store-operated calcium channel (SOCC) blocker gadolinium chloride hexahydrate $\left(\mathrm{Gd}^{3+}: 10^{-6}\right.$ and $\left.5 \times 10^{-6} \mathrm{M}\right)$ [16-19]. We added the above-mentioned inhibitors into the organ bath 20 min prior to the addition of mepivacaine into organ bath. Increasing concentrations of mepivacaine were added to the organ bath after the low concentration caused a stable and sustained contraction for $5 \mathrm{~min}$. In addition, we investigated the effect of calcium-free and low-calcium concentration solutions on mepivacaine-induced vasoconstriction in the aortas without endothelium. The aortas were incubated with either low calcium ( $1 \mathrm{mM}$ ) containing normal Krebs solution or Krebs solution without calcium containing $2 \mathrm{mM}$ ethylene glycol-bis ( $\beta$-aminoethyl ether)-N,N,N,N,-tetraacetic acid for 20 min prior to the addition of mepivacaine [16].

\section{Fura-2 loading and measurement of $\left[\mathrm{Ca}^{2+}\right]_{\mathrm{i}}$}

Preparation for fura-2 loading and measurement of $\left[\mathrm{Ca}^{2+}\right]_{\mathrm{i}}$ were performed as described previously $[9,20]$. Anesthesia of male Sprague-Dawley rats (250-300 g) was induced through an intra- 
peritoneal administration of pentobarbital sodium $(50 \mathrm{mg} / \mathrm{ml})$ and bleeding from the common carotid artery was induced. We dissected the descending thoracic aorta as described in the tension measurement section. Eighteen rats were used in this protocol. $\left[\mathrm{Ca}^{2+}\right]_{\mathrm{i}}$ was measured according to the method described by previous researches using the fluorescent $\mathrm{Ca}^{2+}$ indicator fura$2[9,20]$. We exposed muscle strips to the acetoxymethyl ester of fura-2 (fura-2/AM, $10 \mu \mathrm{M}$ ) with $0.02 \%$ cremophor EL for $5-6 \mathrm{~h}$ at room temperature $[9,20]$. After loading, we washed muscle strips with a physiological salt solution at $37^{\circ} \mathrm{C}$ for 20 min to remove uncleaved fura-2/AM and muscle strips were held horizontally in a temperature-controlled, $7 \mathrm{ml}$ organ bath. The muscle strips were illuminated alternately $(48 \mathrm{~Hz})$ at two excitation wavelengths (340 and $380 \mathrm{~nm}$ ). The level of 500-nm fluorescence (F340 and F380) was detected using a fluorometer (CAF-100; Jasco, Tokyo, Japan). The ratio of F340 to F380 (F340/ F380) was regarded as an amount of $\left[\mathrm{Ca}^{2+}\right]_{\mathrm{i}}$. Absolute $\mathrm{Ca}^{2+}$ concentration was not measured in our experiment because the dissociation constant of the fluorescence indicator for $\mathrm{Ca}^{2+}$ in cytosol may differ from that obtained in vitro [21]. Therefore, the ratios of F340/F380 obtained in resting and $60 \mathrm{mM} \mathrm{KCl}$ stimulated aortic muscle were regarded as $0 \%$ and $100 \%$, respectively. Ratios of F340/F380 were detected with a PowerLab/400 using a chart program (AD Instruments, Colorado Springs, CO, USA). Muscle strips were placed under an initial 3.0 g resting tension. All strips that came from the same animal were used in different experimental protocols. Mepivacaine-induced dose $\left(3 \times 10^{-5}\right.$ to $\left.3 \times 10^{-3} \mathrm{M}\right)$ - $\left[\mathrm{Ca}^{2+}\right]_{\mathrm{i}}$ curves were obtained in muscle strips with or without following inhibitors: verapamil $\left(10^{-7}\right.$ and $\left.10^{-6} \mathrm{M}\right)$, nifedipine $\left(10^{-8}\right.$ and $\left.10^{-7} \mathrm{M}\right), 2$-APB $\left(5 \times 10^{-6}, 10^{-5}\right.$ and $\left.5 \times 10^{-5} \mathrm{M}\right)$ and $\mathrm{Gd}^{3+}\left(10^{-6}\right.$ and $\left.5 \times 10^{-6} \mathrm{M}\right)$ [16-19]. These inhibitors were added to the organ bath 15 min prior to the addition of mepivacaine and remained until the end of experiment. In addition, we investigated the effect of either low calcium (1 mM) containing Krebs solution or Krebs solution without calcium on mepivacaine-evoked concentration- $\left[\mathrm{Ca}^{2+}\right]_{\mathrm{i}}$ curves to determine whether the mepivacaine-induced $\left[\mathrm{Ca}^{2+}\right]_{\mathrm{i}}$ increase was dependent on calcium influx from extracellular fluid [16].

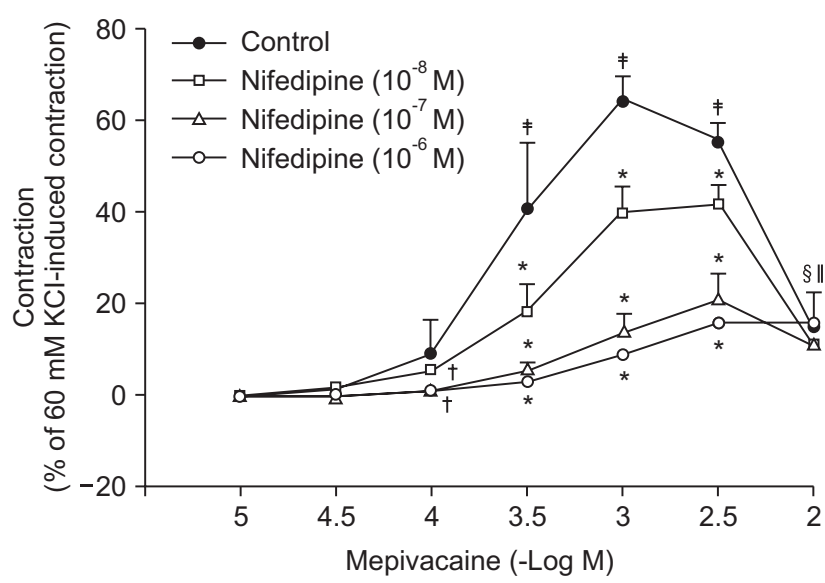

Fig. 1. Effect of nifedipine on mepivacaine-induced dose-response curves in aortas without endothelium. All values are expressed as the means \pm SD (control: $\mathrm{n}=6 ; 10^{-8} \mathrm{M}$ nifedipine: $\mathrm{n}=4 ; 10^{-7} \mathrm{M}$ nifedipine: $\mathrm{n}=6 ; 10^{-6} \mathrm{M}$ nifedipine: $\mathrm{n}=6$ ) and are expressed as percentages of the maximum contraction evoked by isotonic $60 \mathrm{mM} \mathrm{KCl}$. N displays the number of rats from which the descending thoracic aortas were derived. $* \mathrm{P}<0.001$ and ${ }^{\dagger} \mathrm{P}<0.05$ versus control. ${ }^{\dagger} \mathrm{P}<0.001$ and ${ }^{\circledR} \mathrm{P}<$ 0.01 versus $10^{-5} \mathrm{M}$ mepivacaine in control. ${ }^{\text {I }} \mathrm{P}<0.001$ versus $3 \times 10^{-3} \mathrm{M}$ mepivacaine in control.
A

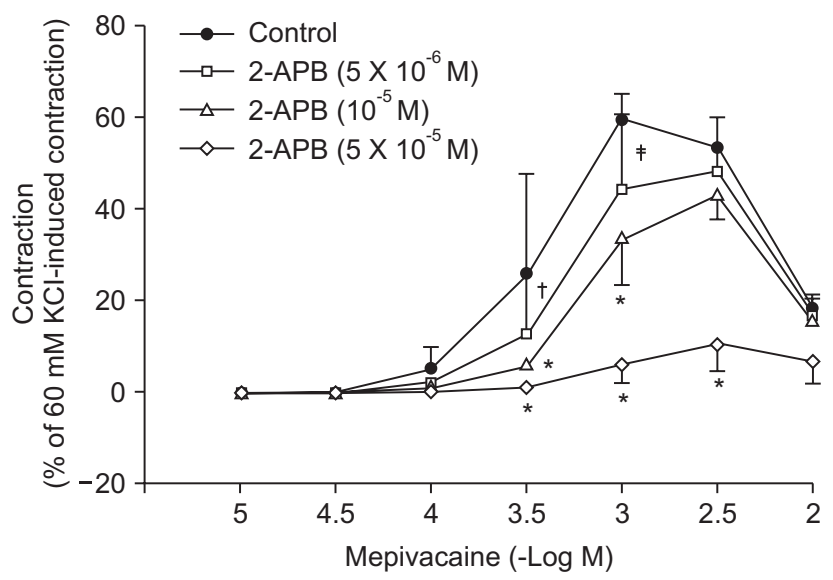

B

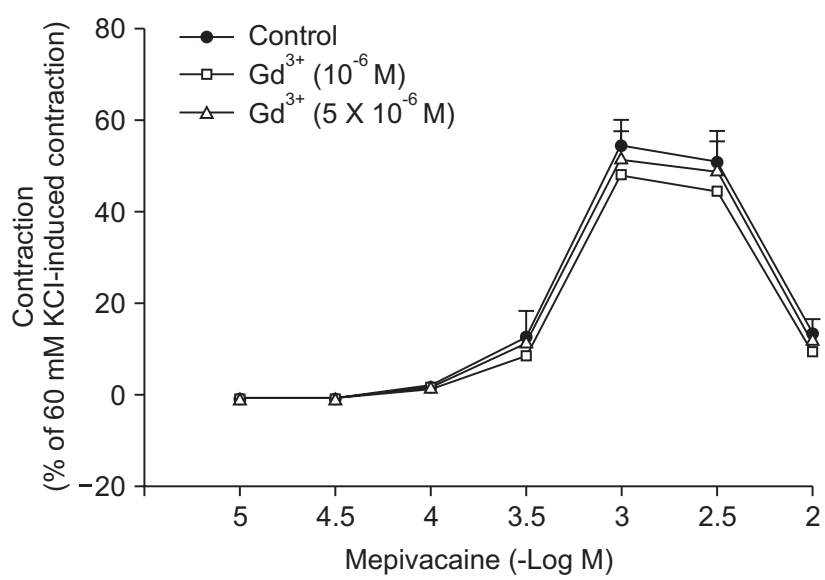

Fig. 2. Effect of 2-aminoethoxydiphenylborate (2-APB, A) and gadolinium chloride hexahydrate $\left(\mathrm{Gd}^{3+}, \mathrm{B}\right)$ on mepivacaine-evoked dose-response curves in aortas without endothelium. All values are expressed as the means \pm SD $(A: n=5, B: n=6)$ and expressed as percentages of the maximum contraction evoked by isotonic $60 \mathrm{mM} \mathrm{KCl}$. $\mathrm{N}$ displays the number of rats from which the descending thoracic aortas were derived. $* \mathrm{P}<0.001$, ${ }^{\dagger} \mathrm{P}<0.05$, and ${ }^{\ddagger} \mathrm{P}<0.01$ versus control. 


\section{Drug}

All drugs were commercially available. Verapamil, nifedipine, L-NAME and $\mathrm{Gd}^{3+}$ were obtained from Sigma Chemical Co. (St Louis, MO, USA), 2-APB from Calbiochem (San Diego, CA, USA), and fura-2/AM (a calcium indicator) from Molecular Probes (Eugene, OR, USA). Mepivacaine was donated by Hana Pharmaceutical Co., Ltd. (Hwaseong, Korea). All concentrations are shown as the final molar concentration in the organ chamber. Nifedipine and 2-APB were dissolved in dimethyl sulfoxide (DMSO; final organ bath concentration: 0.1\% DMSO). Unless

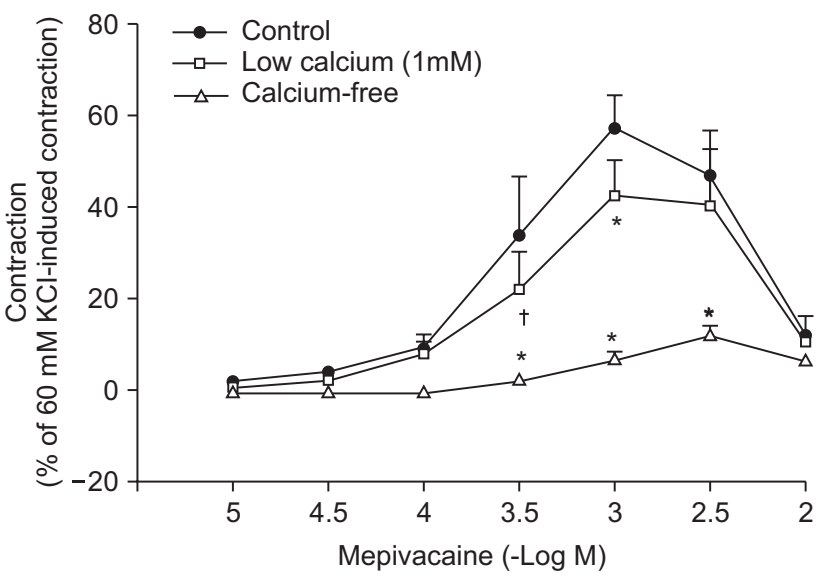

Fig. 3. Effect of low calcium $(1 \mathrm{mM})$ and Krebs solution without calcium on mepivacaine dose-response curves in aortas without endothelium. All values are expressed as the means $\pm \mathrm{SD}(\mathrm{n}=5)$ and expressed as percentages of the maximum contraction evoked by isotonic $60 \mathrm{mM}$ $\mathrm{KCl}$. N displays the number of rats from which descending thoracic aortas were derived. $* \mathrm{P}<0.001$ and ${ }^{\dagger} \mathrm{P}<0.05$ versus control.

A

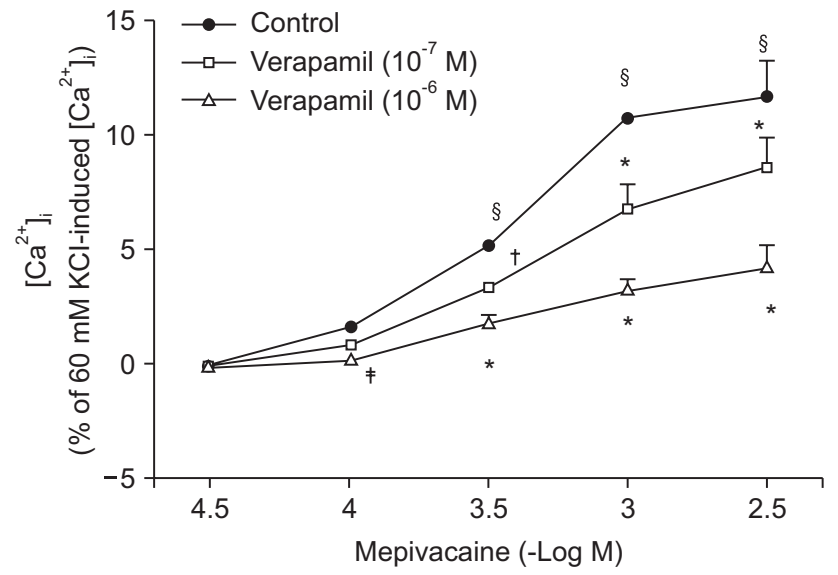

otherwise stated, we dissolved and diluted all other drugs in distilled water.

\section{Data analysis}

Data are shown as the means \pm SD. Vasoconstrictions evoked by mepivacaine are expressed as percentages of the maximum contraction evoked by isotonic $60 \mathrm{mM} \mathrm{KCl}$. The $\left[\mathrm{Ca}^{2+}\right]_{\mathrm{i}}$ changes induced by mepivacaine are shown as percentages of the maximum $\left[\mathrm{Ca}^{2+}\right]_{\mathrm{i}}$ increment evoked d by isotonic $60 \mathrm{mM} \mathrm{KCl}$. Vasoconstriction or $\left[\mathrm{Ca}^{2+}\right]_{\mathrm{i}}$ in response to each mepivacaine concentration were compared using repeated measures analysis of variance (ANOVA) followed by the Bonferroni post-test. Regarding the effects of the inhibitor on the contraction and mepivacaine-induced $\left[\mathrm{Ca}^{2+}\right]_{\mathrm{i}}$ increase, the statistical analysis was analyzed using two-way repeated measure ANOVA followed by Bonferroni's multiple comparison test. Statistical analysis was performed with GraphPad Prism version 5.00 for Windows (GraphPad Software, San Diego, CA, USA). P values less than 0.05 were considered significant.

\section{Results}

Mepivacaine $\left(3 \times 10^{-4}\right.$ to $\left.3 \times 10^{-3} \mathrm{M}\right)$ caused vasoconstriction ( $\mathrm{P}<0.001$ versus $10^{-5} \mathrm{M}$ mepivacaine) followed by attenuated vasoconstriction at $10^{-2} \mathrm{M}$ mepivacaine $\left(\mathrm{P}<0.01\right.$ versus $10^{-5} \mathrm{M}$ mepivacaine; $\mathrm{P}<0.001$ versus $3 \times 10^{-3} \mathrm{M}$ mepivacaine) (Fig. 1). VOCC inhibitor nifedipine $\left(10^{-8}, 10^{-7}\right.$ and $\left.10^{-6} \mathrm{M}\right)$ inhibited mepivacaine-evoked vasoconstriction $(\mathrm{P}<0.05$ versus control at $10^{-4} \mathrm{M}$ mepivacaine, $\mathrm{P}<0.001$ versus control at $3 \times 10^{-4}$ to $3 \times$ $10^{-3} \mathrm{M}$ mepivacaine, Fig. 1). $\mathrm{IP}_{3}$ receptor blocker 2-APB $\left(5 \times 10^{-6}\right.$,

B

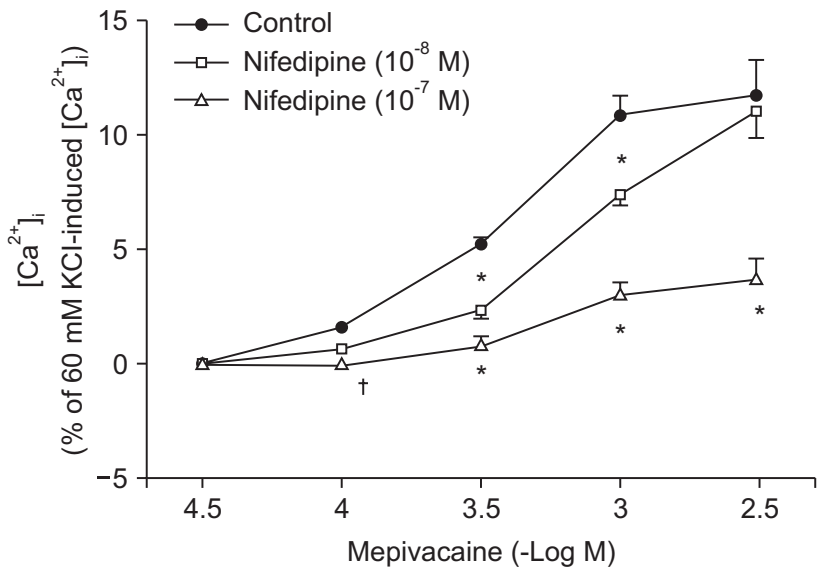

Fig. 4. Effect of verapamil (A) and nifedipine (B) on mepivacaine-evoked intracellular calcium level $\left(\left[\mathrm{Ca}^{2+}\right]_{\mathrm{i}}\right)$ in fura-2 loaded aortic strips. The ratio of F340 to F380 (F340/F380) was regarded as an amount of $\left[\mathrm{Ca}^{2+}\right]_{\mathrm{i}}$. Each point indicates the mean of 5-6 experiments, and SD is expressed as the vertical bars. Data are expressed as percentages of the maximum $\left[\mathrm{Ca}^{2+}\right]_{\mathrm{i}}$ evoked by isotonic $60 \mathrm{mM} \mathrm{KCl} .{ }^{*} \mathrm{P}<0.001,{ }^{\dagger} \mathrm{P}<0.01$, and ${ }^{\dagger} \mathrm{P}<0.05$ versus control. A: ${ }^{\S} \mathrm{P}<0.001$ versus $3 \times 10^{-5} \mathrm{M}$ mepivacaine in control. 
A

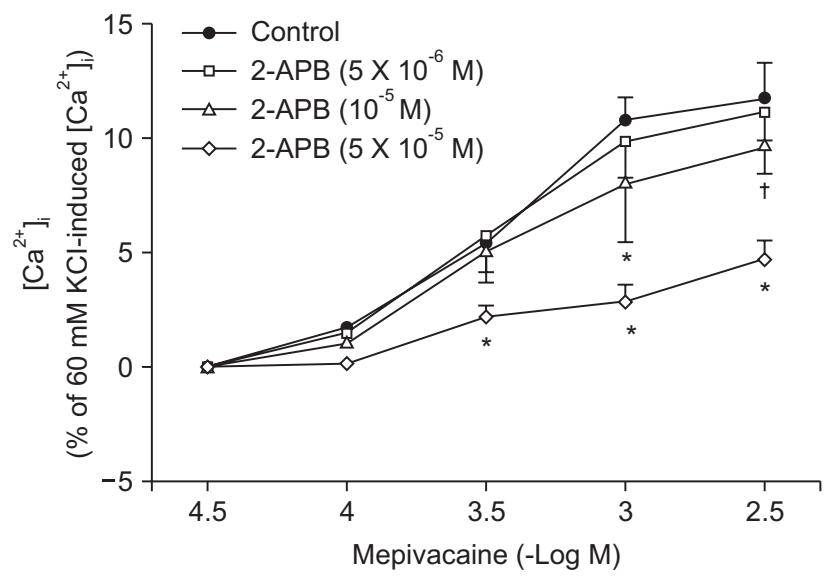

B

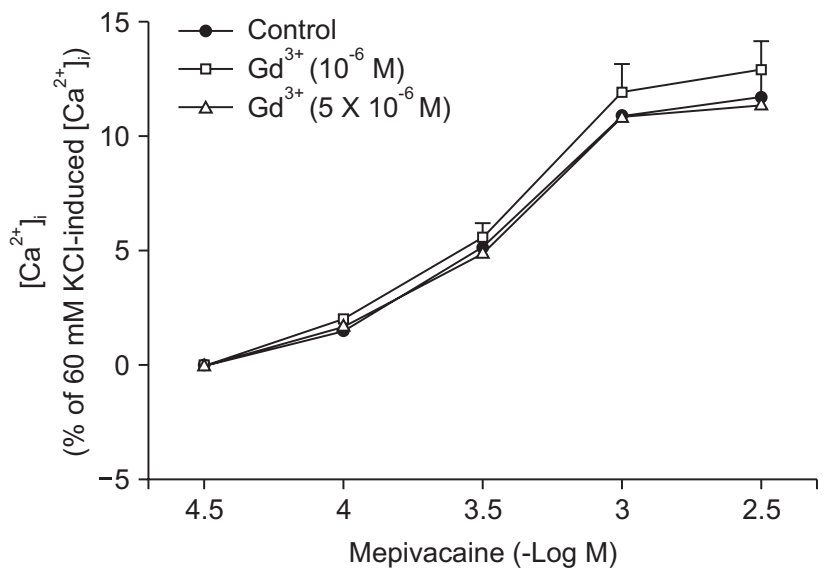

Fig. 5. Effect of 2-aminoethoxydiphenylborate (2-APB, A) and gadolinium chloride hexahydrate $\left(\mathrm{Gd}^{3+}, \mathrm{B}\right)$ on mepivacaine-evoked intracellular calcium level $\left(\left[\mathrm{Ca}^{2+}\right]_{\mathrm{i}}\right)$ in fura-2 loaded aortic strips. The ratio of F340 to F380 (F340/F380) was regarded as an amount of $\left[\mathrm{Ca}^{2+}\right]_{\mathrm{i} \text {. }}$ Each point indicates the mean of 5-6 experiments, and SD is expressed as the vertical bars. Data are expressed as percentages of the maximum $\left[\mathrm{Ca}^{2+}\right]_{\mathrm{i}}$ evoked by isotonic $60 \mathrm{mM} \mathrm{KCl} .{ }^{*} \mathrm{P}<0.001$ and ${ }^{\dagger} \mathrm{P}<0.05$ versus control.

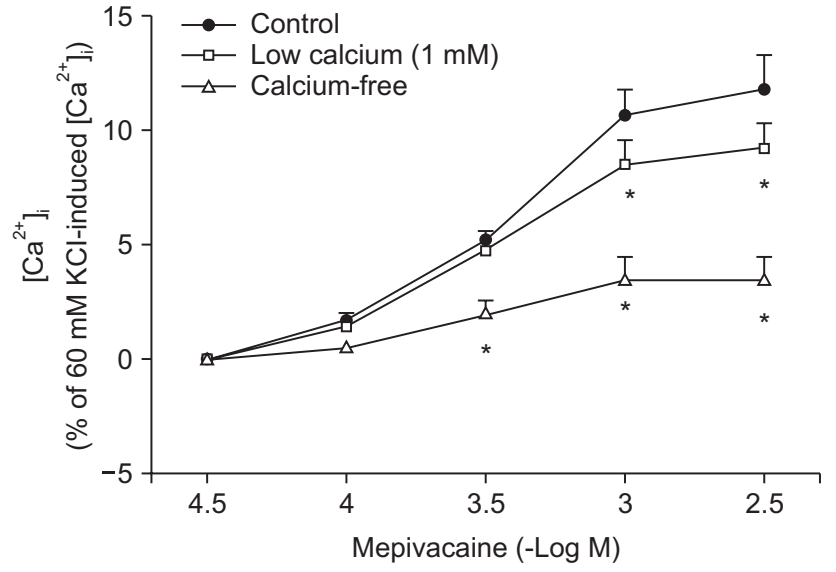

Fig. 6. Effect of low calcium level $(1 \mathrm{mM})$ and Krebs solution without calcium on mepivacaine-evoked intracellular calcium level $\left(\left[\mathrm{Ca}^{2+}\right]_{\mathrm{i}}\right)$ in fura-2 loaded aortic strips. The ratio of F340 to F380 (F340/F380) was regarded as an amount of $\left[\mathrm{Ca}^{2+}\right]_{i}$. Each point indicates the mean of 5-6 experiments, and $\mathrm{SD}$ is shown as the vertical bars. Data are expressed as percentages of the maximum $\left[\mathrm{Ca}^{2+}\right]_{\mathrm{i}}$ evoked by isotonic $60 \mathrm{mM} \mathrm{KCl}$. $* \mathrm{P}<0.001$ versus control.

$10^{-5}$ and $\left.5 \times 10^{-5} \mathrm{M}\right)$ attenuated mepivacaine-evoked vasoconstriction $\left(\mathrm{P}<0.05\right.$ versus control at $3 \times 10^{-4}$ and $10^{-3} \mathrm{M}$ mepivacaine) (Fig. $2 \mathrm{~A}$ ). However, the SOCC blocker $\mathrm{Gd}^{3+}$ had no effect on mepivacaine-evoked vasoconstriction (Fig. 2B). A low calcium level $(1 \mathrm{mM})$ significantly decreased the mepivacaineevoked vasoconstriction $\left(\mathrm{P}<0.05\right.$ versus control at $3 \times 10^{-4} \mathrm{M}$ and $\mathrm{P}<0.001$ versus control at $10^{-3} \mathrm{M}$ mepivacaine, Fig. 3), and Krebs solution without calcium almost abolished mepivacaineevoked vasoconstriction $\left(\mathrm{P}<0.001\right.$ versus control at $3 \times 10^{-4}$ to $3 \times 10^{-3} \mathrm{M}$ mepivacaine, Fig. 3).

Mepivacaine $\left(3 \times 10^{-4}\right.$ to $\left.3 \times 10^{-3} \mathrm{M}\right)$ increased $\left[\mathrm{Ca}^{2+}\right]_{\mathrm{i}}(\mathrm{P}<$
0.001 versus $3 \times 10^{-5} \mathrm{M}$ mepivacaine, Fig. $\left.4 \mathrm{~A}\right)$. The VOCC inhibitors verapamil $\left(10^{-7}\right.$ and $\left.10^{-6} \mathrm{M}\right)$ and nifedipine $\left(10^{-8}\right.$ and $\left.10^{-7} \mathrm{M}\right)$ attenuated the mepivacaine-induced $\left[\mathrm{Ca}^{2+}\right]_{\mathrm{i}}$ increase $\left(\mathrm{P}<0.01\right.$ versus control at $3 \times 10^{-4}$ and $10^{-3} \mathrm{M}$ mepivacaine, Fig. $4 \mathrm{~A}$ and $\mathrm{B})$. The $\mathrm{IP}_{3}$ receptor blocker $2-\mathrm{APB}\left(10^{-5}\right.$ and $5 \times$ $\left.10^{-5} \mathrm{M}\right)$ inhibited the mepivacaine-evoked $\left[\mathrm{Ca}^{2+}\right]_{\mathrm{i}}$ increase $\left(10^{-5} \mathrm{M}\right.$ 2-APB: $\mathrm{P}<0.001$ versus control at $10^{-3} \mathrm{M}$ mepivacaine, $\mathrm{P}<0.05$ versus control at $3 \times 10^{-3} \mathrm{M}$ mepivacaine; $5 \times 10^{-5} \mathrm{M} 2$-APB: $\mathrm{P}<0.001$ versus control at $3 \times 10^{-4}$ to $3 \times 10^{-3} \mathrm{M}$ mepivacaine, Fig. $5 \mathrm{~A}$ ), whereas the SOCC inhibitor $\mathrm{Gd}^{3+}$ had no effect on the mepivacaine-evoked $\left[\mathrm{Ca}^{2+}\right]_{\mathrm{i}}$ increment (Fig. 5B). Low calcium concentration $(1 \mathrm{mM})$ attenuated the mepivacaine-induced $\left[\mathrm{Ca}^{2+}\right]_{\mathrm{i}}$ increase $\left(\mathrm{P}<0.001\right.$ versus control at $10^{-3}$ and $3 \times 10^{-3}$ $\mathrm{M}$ mepivacaine, Fig. 6). Calcium-free Krebs solution strongly inhibited the mepivacaine-induced $\left[\mathrm{Ca}^{2+}\right]_{\mathrm{i}}$ increase $(\mathrm{P}<0.001$ versus control at $3 \times 10^{-4}$ to $3 \times 10^{-3} \mathrm{M}$ mepivacaine, Fig. 6).

\section{Discussion}

Taking the results together, this is first study to suggest that the mepivacaine-induced $\left[\mathrm{Ca}^{2+}\right]_{i}$ increase associated with mepivacaine-induced contraction seems to be mainly dependent on the calcium influx from extracellular space. The main findings of current study were as follows: 1) nifedipine and 2-APB inhibited mepivacaine-evoked vasoconstriction; 2) low calcium level inhibited mepivacaine-evoked vasoconstriction, and Krebs solution without calcium almost abolished mepivacaine-evoked vasoconstriction; 3) verapamil, nifedipine, 2-APB and low calcium level inhibited the mepivacaine-induced $\left[\mathrm{Ca}^{2+}\right]_{\mathrm{i}}$ increase; and 4) calcium-free solution strongly attenuated the mepivacaineinduced $\left[\mathrm{Ca}^{2+}\right]_{\mathrm{i}}$ increase. 
Vasoconstriction induced by a receptor-mediated contractile agonist (example: phenylephrine) involves $\left[\mathrm{Ca}^{2+}\right]_{\mathrm{i}}$ increase via both calcium influx from extracellular fluid and calcium released from the sarcoplasmic reticulum [22]. Calcium influx that contributes to phenylephrine-evoked vasoconstriction is mediated by VOCC and receptor-mediated calcium channels [22-24]. $\mathrm{IP}_{3}$ receptor-induced calcium release from sarcoplasmic reticulum causes transient initial vasoconstriction evoked by phenylephrine [22]. Consistent with the results of previous reports, VOCC inhibitor nifedipine inhibited mepivacaine-induced contraction and the highest concentration $\left(10^{-6} \mathrm{M}\right)$ of nifedipine almost inhibited mepivacaine-evoked vasoconstriction, suggesting that mepivacaine-evoked vasoconstriction involves activation of VOCC [7-9]. 2-APB, a blocker of $\mathrm{IP}_{3}$ receptor associated with calcium release from the sarcoplasmic reticulum, inhibited mepivacaine-evoked vasoconstriction, suggesting that mepivacaine-evoked vasoconstriction involves $\mathrm{IP}_{3}$ receptor-induced calcium release from the sarcoplasmic reticulum $[17,18]$. However, 2-APB is a inhibitor not only of $\mathrm{IP}_{3}$ receptor but also of SOCC [17,18,25-27]. Therefore, the inhibitory effect of 2-APB on mepivacaine-evoked vasoconstriction may be associated with the blockade of SOCC rather than that of the $\mathrm{IP}_{3}$ receptor. To rule out 2-APB-induced SOCC inhibition as a contributor to the inhibition of mepivacaine-induced contraction, we evaluated the effect of SOCC inhibitor $\mathrm{Gd}^{3+}$ on mepivacaine-evoked vasoconstriction. Because $\mathrm{Gd}^{3+}$ had no effect on mepivacaine-evoked vasoconstriction, the inhibitory effect of 2 -ABP on mepivacaineevoked vasoconstriction appears to be due to inhibition of $\mathrm{IP}_{3}$ receptor. Furthermore, a low calcium concentration (1 mM) inhibited mepivacaine-evoked vasoconstriction, and Krebs solution without calcium almost abolished the effect. Taken together, these results suggest that mepivacaine-evoked vasoconstriction seems to be mediated mainly by calcium influx via VOCC and partially by calcium released from the sarcoplasmic reticulum. Further research to investigate the mechanism that is responsible for high-dose $\left(10^{-3} \times 3\right.$ and $\left.10^{-2} \mathrm{M}\right)$ mepivacaine-induced attenuated vasoconstriction is thus required.

To confirm that mepivacaine-evoked vasoconstriction is mainly dependent on calcium influx, as observed in the isometric tension experiment, we assessed the effect of various inhibitors on mepivacaine-evoked $\left[\mathrm{Ca}^{2+}\right]_{\mathrm{i}}$ increase using aortic strips loaded with fura-2. Mepivacaine increased $\left[\mathrm{Ca}^{2+}\right]_{\mathrm{i}}$ (Fig. 4A), which contributes to the mepivacaine-evoked contraction. Consistent with the results from isometric tension measurements in the current study, nifedipine and verapamil attenuated the mepivacaine-induced $\left[\mathrm{Ca}^{2+}\right]_{\mathrm{i}}$ increase. In addition, 2 -APB $\left(10^{-5}\right.$ and 5 $\left.\times 10^{-5} \mathrm{M}\right)$ attenuated the mepivacaine-induced $\left[\mathrm{Ca}^{2+}\right]_{\mathrm{i}}$ increase, whereas $\mathrm{Gd}^{3+}$ had no effect. Taken together, the mepivacaine $\left(3 \times 10^{-4}\right.$ to $\left.3 \times 10^{-3} \mathrm{M}\right)$-induced $\left[\mathrm{Ca}^{2+}\right]_{\mathrm{i}}$ increment seems to be mediated by both calcium influx through VOCC and calcium released from the sarcoplasmic reticulum. Furthermore, because a low calcium concentration attenuated the mepivacaine-evoked $\left[\mathrm{Ca}^{2+}\right]_{\mathrm{i}}$ increment and Krebs solution without calcium strongly inhibited the mepivacaine-evoked $\left[\mathrm{Ca}^{2+}\right]_{\mathrm{i}}$ increment, the mepivacaine-evoked $\left[\mathrm{Ca}^{2+}\right]_{\mathrm{i}}$ increment appears to be primarily dependent on calcium influx through VOCC. Further research regarding the upper cellular signal pathway responsible for the mepivacaine-induced $\left[\mathrm{Ca}^{2+}\right]_{\mathrm{i}}$ increase is needed to elucidate detailed signal pathway. In agreement with a previous study that enhanced calcium sensitivity evoked by Rho-kinase and protein kinase $\mathrm{C}$ contributes to mepivacaine-induced contraction, maximum contraction induced by mepivacaine was $65 \pm 5 \%$ of 60 $\mathrm{mM} \mathrm{KCl-induced} \mathrm{contraction} \mathrm{(Fig.} \mathrm{1),} \mathrm{whereas} \mathrm{the} \mathrm{maximum}$ $\left[\mathrm{Ca}^{2+}\right]_{\mathrm{i}}$ induced by mepivacaine was $12 \pm 5 \%$ of $60 \mathrm{mM} \mathrm{KCl}$-induced maximum $\left[\mathrm{Ca}^{2+}\right]_{\mathrm{i}}$ (Fig. $4 \mathrm{~A}$ ), suggesting that mepivacaineevoked vasoconstriction is mediated both mainly by calcium sensitization and partially by increment of $\left[\mathrm{Ca}^{2+}\right]_{\mathrm{i}}[9]$.

The clinical relevance of mepivacaine-induced contraction mainly mediated by an increment in $\left[\mathrm{Ca}^{2+}\right]_{\mathrm{i}}$ via calcium influx must be tempered by the following factors. First, we used the aorta, which has a role as conduit vessel, whereas small resistance arterioles regulate organ blood flow such as perineural blood flow [28]. Second, endothelial nitric oxide inhibits contraction evoked by mepivacaine [7]. In addition, the shear stressinduced nitric oxide release by blood flow in vivo would inhibit mepivacaine-induced vasoconstriction [29]. Considering these factors, nitric oxide release in an in vivo state attenuates mepivacaine-induced contraction observed in this in vitro study [7,29]. Despite these limitations, the pale skin color, inhibited capillary blood flow and reactive hyperemia, and reduced cutaneous blood flow observed during mepivacaine-evoked analgesia in previous in vivo researches and intermediate-acting period of mepivacaine may be due to mepivacaine-induced vasoconstriction mediated by an increase in $\left[\mathrm{Ca}^{2+}\right]_{\mathrm{i}}[2,4-6,30]$. In addition, mepivacaine-induced contraction may be attenuated in a patient who takes a calcium channel blocker, leading to a short duration of mepivacaine-evoked analgesia compared with a person who does not take a calcium channel blocker. The clinically available concentrations of mepivacaine are between 0.5 and $2 \%$, which approximately corresponds to $1.725 \times 10^{-2}$ to $7 \times 10^{-2} \mathrm{M}$. This concentration produced vasodilation in the current study. However, the clinically available concentrations of mepivacaine produce reduced blood flow and vasoconstriction in vivo [4-6]. This difference in the mepivacaine-induced vascular response between the current study and previous researches may be due both to differences in blood vessels (capillary versus aorta), species (human versus rat) and experimental methods (in vivo versus in vitro) and to the dilution of infiltrated mepivacaine using 
interstitial fluid in an in vivo state. When mepivacaine is locally infiltrated, the local tissue level of mepivacaine may be lower than the commercially available concentration of mepivacaine because locally applied mepivacaine is diluted by interstitial fluid and $77.5 \%$ of mepivacaine is bound to plasma protein [1].

Taken together, these results suggest that the mepivacaineevoked $\left[\mathrm{Ca}^{2+}\right]_{\mathrm{i}}$ increment that contributes to mepivacaine-induced contraction appears to be mediated both primarily by calcium influx via VOCCs and partially by calcium released from the sarcoplasmic reticulum in isolated endothelium-denuded rat aortas.

\section{Acknowledgments}

This research was supported by the Basic Science Research Program through the National Research Foundation of Korea (NRF) funded by the Ministry of Education, Science, and Technology (KRF-2011-0006783). This research was supported by Basic Science Research Program through the National Research Foundation of Korea (NRF) funded by the Ministry of Education (2013R1A1A2057459). The authors thank Jae Young Choi from the Summit Day School for secretarial support in preparing the manuscript.

\section{References}

1. Tagariello V, Caporuscio A, De Tommaso O. Mepivacaine: update on an evergreen local anaesthetic. Minerva Anestesiol 2001; 67(9 Suppl 1): 5-8.

2. Willatts DG, Reynolds F. Comparison of the vasoactivity of amide and ester local anaesthetics. An intradermal study. Br J Anaesth 1985; 57: 1006-11.

3. Wali FA. Effects of local anaesthetics on responses of human saphenous vein and bovine coronary artery to neurotransmitters, acetylcholine, noradrenaline and 5-hydroxytryptamine. Gen Pharmacol 1986; 17: 405-11.

4. Guinard JP, Carpenter RL, Morell RC. Effect of local anesthetic concentration on capillary blood flow in human skin. Reg Anesth 1992; 17: 317-21.

5. Kalman S, Björhn KC, Tholén EK, Lisander B. Mepivacaine as an intravenous regional block interferes with reactive hyperemia and decreases steady-state blood flow. Reg Anesth 1997; 22: 552-6.

6. Kalman S, Linderfalk C, Wårdell K, Eintrei C, Lisander B. Differential effect on vasodilatation and pain after intradermal capsaicin in humans during decay of intravenous regional anesthesia with mepivacaine. Reg Anesth Pain Med 1998; 23: 402-8.

7. Sung HJ, Choi MJ, Ok SH, Lee SH, Hwang IJ, Kim HS, et al. Mepivacaine-induced contraction is attenuated by endothelial nitric oxide release in isolated rat aorta. Can J Physiol Pharmacol 2012; 90: 863-72.

8. Lee HM, Ok SH, Sung HJ, Eun SY, Kim HJ, Lee SH, et al. Mepivacaine-induced contraction involves phosphorylation of extracellular signalregulated kinase through activation of the lipoxygenase pathway in isolated rat aortic smooth muscle. Can J Physiol Pharmacol 2013; 91: 285-94.

9. Ok SH, Kwon SC, Han JY, Yu J, Shin IW, Lee HK, et al. Mepivacaine-induced contraction involves increased calcium sensitization mediated via Rho kinase and protein kinase C in endothelium-denuded rat aorta. Eur J Pharmacol 2014; 723: 185-93.

10. Neal JM. Effects of epinephrine in local anesthetics on the central and peripheral nervous systems: Neurotoxicity and neural blood flow. Reg Anesth Pain Med 2003; 28: 124-34.

11. Sung HJ, Ok SH, Sohn JY, Son YH, Kim JK, Lee SH, et al. Vasoconstriction potency induced by aminoamide local anesthetics correlates with lipid solubility. J Biomed Biotechnol 2012; 2012: 170958.

12. Akata T. General anesthetics and vascular smooth muscle: direct actions of general anesthetics on cellular mechanisms regulating vascular tone. Anesthesiology 2007; 106: 365-91.

13. Busse R, Fleming I, Hecker M. Signal transduction in endothelium-dependent vasodilatation. Eur Heart J 1993; 14 Suppl I: 2-9.

14. Ok SH, Park CS, Kim HJ, Lee SH, Choi BH, Eun SY, et al. Effect of two lipid emulsions on reversing high-dose levobupivacaine-induced reduced vasoconstriction in the rat aortas. Cardiovasc Toxicol 2013; 13: 370-80.

15. Ok SH, Sohn JT, Baik JS, Kim JG, Park SS, Sung HJ, et al. Lipid emulsion reverses levobupivacaine-induced responses in isolated rat aortic vessels. Anesthesiology 2011; 114: 293-301.

16. Baik JS, Sohn JT, Ok SH, Kim JG, Sung HJ, Park SS, et al. Levobupivacaine-induced contraction of isolated rat aorta is calcium dependent. Can J Physiol Pharmacol 2011; 89: 467-76.

17. Maruyama T, Kanaji T, Nakade S, Kanno T, Mikoshiba K. 2APB, 2-aminoethoxydiphenyl borate, a membrane-penetrable modulator of Ins(1,4,5) $\mathrm{P}_{3}$-induced $\mathrm{Ca}^{2+}$ release. J Biochem 1997; 122: 498-505.

18. Laporte R, Hui A, Laher I. Pharmacological modulation of sarcoplasmic reticulum function in smooth muscle. Pharmacol Rev 2004; 56: 439-513.

19. Xu YJ, Tappia PS, Goyal RK, Dhalla NS. Mechanisms of the lysophosphatidic acid-induced increase in $\left[\mathrm{Ca}^{2+}\right]_{\mathrm{i}}$ in skeletal muscle cells. J Cell Mol Med 2008; 12: 942-54.

20. Shim HS, Ok SH, Lee SH, Kwon SC, Sohn JT. Protein kinases participate in the contraction in response to levobupivacaine in the rat aorta. 
Eur J Pharmacol 2012; 677: 131-7.

21. Karaki H. $\mathrm{Ca}^{2+}$ localization and sensitivity in vascular smooth muscle. Trends Pharmacol Sci 1989; 10: 320-5.

22. Karaki H, Ozaki H, Hori M, Mitsui-Saito M, Amano K, Harada K, et al. Calcium movements, distribution, and functions in smooth muscle. Pharmacol Rev 1997; 49: 157-230.

23. Shin IW, Sohn JT, Kim HJ, Kim C, Lee HK, Chang KC, et al. Etomidate attenuates phenylephrine-induced contraction in isolated rat aorta. Can J Anaesth 2005; 52: 927-34.

24. Sohn JT, Park KE, Kim C, Jeong YS, Shin IW, Lee HK, et al. Alfentanil attenuates phenylephrine-induced contraction in rat aorta. Eur J Anaesthesiol 2007; 24: 276-82.

25. Bootman MD, Collins TJ, Mackenzie L, Roderick HL, Berridge MJ, Peppiatt CM. 2-aminoethoxydiphenyl borate (2-APB) is a reliable blocker of store-operated $\mathrm{Ca}^{2+}$ entry but an inconsistent inhibitor of $\mathrm{InsP}_{3}$-induced $\mathrm{Ca}^{2+}$ release. FASEB J 2002; 16: 1145-50.

26. Diver JM, Sage SO, Rosado JA. The inositol trisphosphate receptor antagonist 2-aminoethoxydiphenylborate (2-APB) blocks Ca ${ }^{2+}$ entry channels in human platelets: cautions for its use in studying $\mathrm{Ca}^{2+}$ influx. Cell Calcium 2001; 30: 323-9.

27. Dobrydneva Y, Blackmore P. 2-Aminoethoxydiphenyl borate directly inhibits store-operated calcium entry channels in human platelets. Mol Pharmacol 2001; 60: 541-52.

28. Christensen KL, Mulvany MJ. Location of resistance arteries. J Vasc Res 2001; 38: 1-12.

29. Lu D, Kassab GS. Role of shear stress and stretch in vascular mechanobiology. J R Soc Interface 2011; 8: 1379-85.

30. Felice K, Schumann H. Intravenous lipid emulsion for local anesthetic toxicity: a review of the literature. J Med Toxicol 2008; 4: 184-91. 